TEME, г. ХLII, бр. 3, јул - септембар 2018, стр. 1019-1041

Прегледни рад

Примљено: 25. 4. 2017.

DOI: $10.22190 /$ TEME1803019M

Ревидирана верзија: 12. 3. 2018.

UDK $342.72 / .73$

Одобрено за штампу: 12. 6. 2018.

\title{
АСПЕКТИ МЕДИЦИНСКОГ ПРАВА У РЕГУЛАМА ТРАНСПОРТНЕ МЕДИЦИНЕ ${ }^{a^{*}}$
}

\author{
Хајрија Мујовић \\ Института друштвених наука у Београду, Центар за правна истраживања, \\ Београд, Србија \\ hmujovic@idn.org.rs
}

\begin{abstract}
Апстракт
Овај чланак има за предмет ближе појашњење улоге и специфичности служби транспорне медицине у збрињавању угрожене популације, односно појединаца који су у хитном стању или критичним ситуацијама. Циљ је да се истражи мера правне уређености и да ли законска и друга регулатива треба да буде ревидирана из разлога достизања боље здравствене заштите угрожених. Истражена регулатива посматра се у контексту извора медицинског права и њиховог односа са важећим правилима и принципима медицинског сталежа. При томе, питања различитих видова транспорта сагледавају се у случајевима кад је превоз хитан и онда кад он није хитан, али се обавља по налогу лекара, било да је реч о међуболничком премештању пацијента, премештању унутар здравствене установе, или на кућно лечење. Резултати правне анализе и приказаног примера из иностране судске праксе јесу да, када је у питању транспорт, нека од права пацијената могу бити суспендована под условом уредног вођења медицинске документације. Мера хитности транспорта обрнуто је сразмерна мери уживања припадајућих права. Закључак је да прописи Србије из области здравствене заштите недовољно обухватају проблеме транспорта пацијената. Мање допуне кроз правилнике и нацрте решења у погледу рада хитних служби новијег су датума и недовољно примењене. Неспорно је да групације или појединци у транспорту завређују бољи квалитет услуга превоза, као и ефикаснију заштиту по притужбама на рад служби. Развијене земље по свом искуству и законодав-
\end{abstract}

\footnotetext{
${ }^{a}$ Рад је настао у оквиру пројекта Људска права и вредности у биомедииини - Демократизачија одлучивања у здравству и илплементација (ОН 179023), подржаног од Министарства просвете, науке и технолошког развоја Републике Србије.

${ }^{*}$ Медицинско право је научна дисциплина која се бави актима и односима пружаоца и примаоца здравствене заштите, а поводом медицинских услуга које се пружају у оквиру професионалних делатности (краће: право у медицини, Memetteau, G. Droit Medical, .Paris, 1986: 4); Транспортна медицина представља негу и премештање критичног или повређеног пацијента са једног места на друго (статус посебне специјалности од 1990. у оквиру анестезиологије и интензивне медицине: https://medical-dictionary.thefreedictionary.com/ Patient+Transport +Services).
} 
ству у том погледу могу представљати добар узор за право Србије. То је веома важно јер данас поједини видови транспорта, на примеру тзв. ваздушних амбуланти у здравственој заштити, добијају међународне размере.

Кључне речи: становништво, пацијенти, хитна стања, кризне ситуације, транспорт.

\title{
THE MEDICAL LAW ASPECTS OF TRANSPORTATION MEDICINE'S REGULATION
}

\begin{abstract}
The subject of this paper is to make closer clarification of the role and the specificities of services in transporting medicine by caring of vulnerable populations, or individuals who are in an emergency condition or critical situations. The field of medical transport presents a few legal questions and challenges. The aim is to research the rate of legal regulation and whether the legal and other regulation should be revised for reasons of achieving better health care of endangered. Issues of performing different types of transport of patients are observed in cases where the transport emergency and when it is not an emergency but is done on the orders of a doctor, be it on intrahospital moving the patient, moving within health facilities, or at home treatment. Each hospital should have a formalized plan for intra- and interhospital transport that addresses: a) pretransport coordination and communication; b) transport personnel; c) transport equipment; d) monitoring during transport; and e) documentation. The transport plan should be developed by a multidisciplinary team and should be evaluated and refined regularly using a standard quality improvement process. Each transport of critically ill patients carries inherent risks. So equally important is a commitment to providing high-quality, compassionate clinical care in a team-based environment with excellent documentation and communication. The results of the legal analysis and the illustrated example from the foreign jurisprudence are that when it comes to transport some of the patients' rights can be suspended under the condition of keeping a medical record properly. The urgency of transport is the reverse of the merits of enjoyment of the corresponding rights. The conclusion is that the regulations Serbia in the field of healthcare under-cover transportation problems of patients. Some amendments to the regulations and draft decisions regarding the current work of emergency services are of more recent date and insufficiently implemented. There is no doubt that groups or individuals in transport deserve a better quality of transport services, as well as the effective protection of the complaints against the department. Developed countries, experiencing and legislation in this regard can be a good model for the Law of Serbia. This is very important because today some aspects of transport, the case of the so-called. air ambulances in the health care, have given international situation.
\end{abstract}

Key words: population, patients, emergencies, crisis situations, transportation.

\section{1. УВОД}

Помоћ другоме у невољи представља моралну заповест људског друштва, која се схвата као дуг части који треба добровољно испуњавати. Тиме се уједно исказује осећање солидарности човека према човеку. 
Све невоље у које човек запада нису увек од истог значаја и не погађају све људе у истој мери. Озбиљне невоље представљају сви догађаји који угрожавају људски живот и здравље. Са правног становишта, тада се говори о дужности свакога да другоме у невољи пружи помоћ и да учествује у отклањању опште опасности (Радишић, 2008). Ако се то повеже са одговорним поступањем према онима код којих су те вредности непосредно угрожене, постају актуелна бројна питања не само са становишта организације, економских фактора већ и поштовања стандарда људских права. С једне стране, држава је у обавези да организује службе које су у стању да хитно реагују и помогну. С друге стране, популација угрожених је некад мање или више бројна и може бити врло хетерогена, чак и маргинализована или врло осетљива, уколико је реч о деци, повређеним или болесним у критичном стању, породиљама или старим особама на крају живота. Главну улогу у здравственом збрињавању становништва свакако имају здравствене службе. Према врсти организације, то су најпре службе хитне медицинске помоћи и одељења интензивне медицинске неге. Уско повезано са таквим, крајње традиционалним организационим облицима, развила се и служба медицинског транспорта, тзв. транспортна медицина ${ }^{1}$, у свим видовима збрињавања угрожених грађана - пацијената и њихове пратње и неге у току трансфера. Транспорт представља процес у којем се роба или људи одређеним путем превозе од једног места до одређене дестинације (Хецкер, Меиер 2017). Иначе, сама реч транспорт појмовно извире из речи логистика, која има грчко порекло. Отуда и медииинска логистика значи логистику у лековима, медицинским средствима, помагалима, опреми и екипама.

Без обзира на то што је њена област рада новијег датума, транспортна медицина завређује пуну пажњу јер постаје све сложенија, многољуднија и технички више унапређена. Поред несумњивих добробити, постоји и свест да све хитне и екстремно захтевне процедуре у медицини носе и повећани ризик, како по онога ко професионално поступа тако и за оног према коме се поступа. Посебно се могу сагледати животне околности и здравствене специфичности у којима се налази угрожена популација, односно појединци којима треба помоћ. Шира питања која су релевантна и која се у пракси могу поставити везана су за специфичности врста транспорта као што су интрахоспитални и интерхоспитални транспорт, али и питања различитих проблема у примени критеријума за одабир, време, безбедност транспорта, затим и питања физиологије и стреса пацијента

\footnotetext{
${ }^{1}$ Напомена: термин преузет са VIII симпозијума бр. А-1-2198/16 - „Транспорт новорођенчади и педијатријских пацијената”, Служба за анестезију и интензивну терапију ИМД у Београду, новембра 2016.
} 
у транспорту, рада транспортног тима, праћења и специјализоване терапије.

Правна квалификација различитих поступака у крајње специфичним ситуацијама транспортне медицине полази најпре од општих питања здравствене заштите и доследне примене прописа у вези са тим. Наиме, пружање здравствене заштите обавља се из разлога који може бити у томе да се оствари превенција, лечење или рехабилитација лица. Ипак, такву заштиту не обележавају само уобичајене ситуације. Некад долази до кризних, или како се још називају, екстремних ситуација онда кад се медицинска помоћ указује групацијама становништва или појединцима који су у посебном стању угрожености. У сваком од тих случајева професионално обављање здравствених делатности стоји у непосредној вези са дужношћу да се пружа здравствена заштита онима који је затраже. У свакодневној медицинској пракси постоје различите врсте транспорта у виду премештања оболелих ради дијагностике, терапије или оперативних захвата. На медицинској страни постоји обавеза да се суочи са ризицима и користима транспорта имајући пре свега у виду добробит онога ко се транспортује. Интерес оболелог или повређеног увек треба да буде у првом плану и управо ту се читава проблематика транспорта фокусира на аспект медицинског права. Наиме, у другом плану, али и даље важни, треба да буду економски или неки други технички аспекти. То се често заборавља и од тога пати и постојећа медицинска регулатива, која дефинише претежно професионалне аспекте, а недовољно сагледава положај појединца у стању угрожености када му је потребан транспорт и приступ самој институцији, одређеном третману или чак и кућном лечењу. Због ширине проблематике, ово разматрање усредсређујемо само на основна питања рада транспортне медицине, пре свега са намером да укаже на потребну бригу за положај корисника транспорта у здравственом систему Србије. Аспекти медицинског права су у том смислу веома битни. Медицинско право има дугу традицију у изучавању питања правних односа у којима учествује лекар као страна која обавља лечење или другу врсту третмана (Savatier, 1862). У прошлости се у почецима те дисциплине истицало да она треба да буде принципијелно посао правника и да се разликује од правне медицине, која треба принципијелно да буде посао лекара. Прва поставља проблеме права у односу на медицину, а друга проблеме медицине у односу на право. У данашње време већина правних писаца полази од уџбеничке дефиниције по којој медичинско право у објективном смислу чини скуп правних норми којима се уређује медицинска делатност, утврђују својства лица која ту делатност обављају и њихов однос са корисницима услуга које пружају (Радишић, 2008). Нека од питања која покрећу аспекти медицинског права у контексту услуге превоза 
и уопште премештања угрожених или оболелих као пацијената могу бити следећа: да ли постоје захтеви за специфичним третманом током транспорта, да ли стање болесника захтева минимум времена које би се потрошило у транспорту, да ли локација има добар приступ, да ли је омогућена пратња педијатријског пацијента, у којој мери се може прихватити захтев пацијента у транспорту и др.

\section{2. ПРАВНИ ОКВИР}

Област која покрива обављање здравствених делатности у Републици Србији уређена је како системским тако и посебним законима. Сва општа и посебна правна акта укључена су и део су правног система, почев од Устава (Сл. гласник, 83/2006, чл. 68), па до подзаконских аката и корпуса етичких и сталешких прописа везано за медицинске процедуре и важеће стандарде. Професионални статус лекара и других здравствених радника у одлучивању о осетљивим питањима људског живота и здравља подразумева посебну личну одговорност и дужност лекара да пружа одговарајуће здравствене услуге, што је, кад је у питању лекарска професија, предвиђено правилима професионалне етике (Сл. гласник, 104/2016, чл. 5). Носиоци послова здравствене делатности су по закону здравствене установе и други облици делатности (приватна пракса) који заједно чине здравствену службу. Пружање здравствених услуга битна је одредница ове професије (Сл. гласник, 106/2015, чл. 3). Организовањем рада здравствених служби оснива се један од облика јавне службе ради спровођења и обезбеђивања здравствене заштите грађана и за коју се по закону обезбеђују средства за спровођење здравствене заштите, као и за рад и развој службе, сходно важећем закону (Сл. гласник, 106/2015, чл. 5 и чл. 7).

Здравствена делатност обухвата спровођење мера и активности здравствене заштите које се спроводе у складу са здравственом доктрином и уз употребу здравствених технологија. Прописи налажу да мере и активности буду засноване на научним доказима, безбедне, сигурне и ефикасне, те у складу са начелима професионалне етике. На дужност пружања здравствене заштите директно утичу одредбе о садржини, обиму и стандарду услуга из прописа о здравственом осигурању. Под садржином здравствене заштите подразумевају се поступци и методи дијагностике, лечења и рехабилитације ради спречавања, сузбијања, раног откривања и лечења болести, повреда и других поремећаја здравља, а који су обухваћени обавезним здравственим осигурањем. Под обимом здравствене заштите подразумева се број и дужина трајања поступака и метода дијагностике, лечења и рехабилитације, као и друге величине којима се може изразити обим појединих садржаја здравствене заштите (систематско пружање здрав- 
ствених услуга у одређеном временском периоду и др.), а који чине садржину права из обавезног здравственог осигурања. Законом се такође прописује да се под стандардима здравствене заштите подразумевају услови за коришћење поступака и метода који чине садржину права из обавезног здравственог осигурања, укључујући ограничења за коришћење и начин пружања тих здравствених услуга (Сл. гласник 12/2016, чл. 2 и чл. 3).

Здравствене услуге пружају се у превентивне, дијагностичке, терапијске и рехабилитационе сврхе. Пацијент је онај коме се пружа услуга, односно лице које затражи или коме се пружа здравствена услуга ради очувања и унапређења здравља, спречавања, сузбијања и раног откривања болести, повреда и других поремећаја здравља и благовременог и ефикасног лечења и рехабилитације (Сл. гласник PC, 45/2013, чл. 2). Закон прописује и штити као општи интерес у здравственој заштити хитну медицинску помоћ особама непознатог пребивалишта, као и другим лицима која право на хитну медицинску помоћ не остварују на другачији начин у складу са законом (Сл. гласник, 106/2015, чл. 18). Предвиђа се такође да је свака здравствена установа, као и друга правна лица која обављају одређене послове здравствене делатности у складу са законом, дужна да води здравствену документацију и евиденцију и да у прописаним роковима доставља индивидуалне, збирне и периодичне извештаје на начин прописан посебним законом, при чему се гарантује тајност података из медицинске документације пацијената (Сл. гласник, 106/2015, чл. 73).

Када је у питању организација службе превоза пацијената, закон највише простора даје хитној служби и предвиђа обавезу сваког дома здравља да обезбеди санитетски превоз ако та служба није организована у болници или у другој здравственој установи на територији за коју је дом здравља основан (Сл. гласник 106/2015, чл. 95). Хитна медицинска помоћ је минимум захтева и када су у питању организоване здравствене амбуланте и здравствене станице, у складу са Планом мреже (Сл. гласник, 106/2015, чл. 97). Закон дефинише рад Завода за хитну медицинску помоћ, као здравствене установе у којима се обавља хитна медицинска помоћ и санитетски превоз акутно оболелих и повређених у друге одговарајуће здравствене установе, превоз пацијената на дијализи, као и снабдевање лековима који се дају у хитним случајевима (Сл. гласник, 106/2015, чл. 105).

Посебна одредба прописује да свака општа болница пружа здравствену заштиту лицима свих узраста оболелих од разних врста болести и да треба да има, између осталог, организовану службу за санитетски превоз за упућивање пацијената у другу здравствену установу на секундарном или терцијарном нивоу. Специјална болница у складу са делатношћу коју обавља обезбеђује такође самостално или преко друге здравствене установе санитетски превоз за упућива- 
ње пацијената у другу здравствену установу на секундарном или терцијарном нивоу (Сл. гласник, 106/2015, чл. 111 и чл. 112).

У оквиру казнених одредби због прекршаја, санкционише се новчаном казном од 300.000 до 1.000 .000 динара свака здравствена установа која: 1) не води здравствену документацију и евиденције, односно ако у прописаним роковима не доставља индивидуалне, збирне и периодичне извештаје надлежном органу, или ако на било који начин наруши тајност података из медицинске документације пацијента, односно ако не заштити медицинску документацију од неовлашћеног приступа, копирања и злоупотребе; 2) не обезбеди минимум процеса рада за време штрајка, односно ако се организује штрајк у здравственој установи која пружа хитну медицинску помоћ (Сл. гласник, 106/2015, чл. 256). Поред тога, новчаним износом од 100.000 до 500.000 динара казниће се здравствени радник или предузетник ако не обезбеде стално доступан санитетски превоз (Сл. гласник, 106/2015, чл. 258).

Код нормирања услуга прегледа и лечења у случају болести и повреда, између осталог, обезбеђује се: 1) указивање хитне медицинске помоћи на месту медицинске хитности или у здравственој установи, односно другом облику здравствене службе; 2) хитан санитетски превоз за болести или повреде које су опасне по живот осигураног лица; 3) санитетски превоз који није хитан, када је оправдан и медицински неопходан (Сл. гласник, 10/2016, чл. 37). Хитан санитетски превоз обухвата превоз санитетским возилом због болести или повреде које су опасне по живот осигураног лица до најближе здравствене установе која је оспособљена за наставак даљег лечења оболелог, односно повређеног. Санитетски превоз који није хитан обухвата превоз до здравствене установе у којој се пружа здравствена заштита која је оправдана и медицински неопходна, као и превоз из здравствене установе до куће осигураног лица. Санитетски превоз који није хитан оправдан је и медицински неопходан у случају да транспорт било којим другим транспортним средством може угрозити живот и здравље осигураног лица (Сл. гласник, 10/2016, чл. 38). У остваривању права на здравствену заштиту из обавезног здравственог осигурања, осигураним лицима обезбеђује се санитетски превоз који није хитан (Сл. гласник, 10/2016, чл. 45). Употребу санитетског возила и налог за коришћење санитетског возила и у овом случају даје изабрани лекар или лекарска комисија (Сл. гласник, 12/2016, чл. 11).

Закон у смислу стандардних услуга које се плаћају на терет обавезног здравственог осигурања дефинише појмове хитне и неопходне здравствене заштите. Тако, хитна медицинска помоћ представља непосредну и тренутну медицинску помоћ која се пружа да би се избегло довођење осигураног лица у животну опасност, односно непоправљиво или озбиљно слабљење или оштећење његовог 
здравља или смрт. Под хитном медицинском помоћи сматра се и медицинска помоћ која се пружи у току од 12 сати од момента пријема осигураног лица да би се избегао очекивани настанак хитног медицинског стања. Неопходна здравствена заштита обухвата здравствену заштиту која је одговарајућа, односно потребна за дијагностику, односно лечење болести или повреда осигураног лица, која је у складу са стандардима добре медицинске праксе у земљи и која није пружена, на захтев осигураног лица или здравственог радника, ради стављања осигураног лица у повољнији положај у односу на друга осигурана лица, односно ради стицања посебних користи за здравствену установу, приватну праксу или здравственог радника. Хитну и неопходну здравствену заштиту у поступку остваривања права осигураних лица из обавезног здравственог осигурања утврђују стручно-медицински органи у поступку остваривања права (Сл. гласник 10/2016, чл. 53).

Осигурана лица имају под одређеним условима право на накнаду трошкова превоза (Сл. гласник, 10/2016, чл. 104-108). Пацијенту може бити одређен пратилац за време путовања или за време путовања и боравка у другом месту, ако је то неопходно. Сматра се да је неопходно уколико се на лечење или лекарски преглед у друго место упућује дете млађе од 18 година живота, односно старије лице које је теже телесно или душевно ометено у развоју. Исто важи и за лице код којег је у току живота због обољења или повреде дошло до губитка појединих телесних или психичких функција, због чега то лице није у могућности да самостално обавља активности свакодневног живота, укључујући слепа, слабовида и глува лица (Сл. гласник, 10/2016, чл. 108).

Уколико се здравствена заштита не обезбеђује у обавезном здравственом осигурању, она може обухватити под тим условима, између осталог, и санитетски превоз у случају када осигурано лице може да буде безбедно транспортовано на други адекватан начин и хитан ваздушни саобраћај у случају када осигурано лице може бити сигурно транспортовано друмским или другим превозом (Сл. гласник, 10/2016, чл. 61, тачка 19).

Подзаконским актима ближе се прописују услови хитне медицинске помоћи у погледу кадрова и неопходне опреме на различитим нивоима здравствене заштите (Сл. гласник, 22/2013, чл. 5, чл. 12 и чл. 18). Уређује се и поступак остваривања права у том делу услуга хитног и посебног збрињавања (Сл. гласник, 1/2013). У случају потребе да се осигурано лице коме је указана хитна медицинска помоћ, ради дефинитивног медицинског збрињавања, упути у другу здравствену установу, давалац који је указао хитну медицинску помоћ дужан је да организује санитетски превоз са медицинским збрињавањем и пратњом одговарајућег здравственог радника у путу. Уколико 
здравствена установа по добијеном позиву за указивање хитне медицинске помоћи није ову помоћ благовремено указала, може да се употреби друго превозно средство до најближе здравствене установе. Оправданост коришћења другог превозног средства процењује лекарска комисија. Употребу санитетског возила и налог за коришћење санитетског возила дају изабрани лекар или лекарска комисиjа. Уз упут који изабрани лекар издаје осигураном лицу за коришћење здравствене заштите, он издаје уједно и налог за употребу санитетског возила за превоз осигураног лица. Оцена лекарске комисије о потреби упућивања осигураног лица на лечење или продужену рехабилитацију садржи и оцену о употреби санитетског возила, ако то захтева здравствено стања осигураног лица. Ако је одобрена употреба возила и право на пратиоца у путу, пратилац може да користи за превоз санитетско возило уколико је то технички изводљиво. Ако то није могуће, пратилац има право на накнаду трошкова превоза. Здравствена установа у којој осигурано лице има изабраног лекара обезбеђује превоз уколико је таква помоћ организована за подручје филијале. Превоз такође обезбеђује стационарна установа осигураном лицу у случају да транспорт другим превозним средством може да угрози живот и здравље осигураног лица. На основу мишљења из отпусне листе о потреби превоза осигураног лица санитетским возилом до места становања, на захтев стационарне установе санитетско возило обезбеђује здравствена установа код које осигурано лице има изабраног лекара. Ако се осигурано лице враћа у место становања после завршеног лечења ван подручја матичне филијале, стационарна установа даје предлог лекарској комисији за одобравање употребе санитетског возила с обзиром на здравствено стање осигураног лица. На основу оцене лекарске комисије, употребу санитетског возила обезбеђује здравствена установа код које осигурано лице има изабраног лекара. Ипак, осигурано лице сноси трошкове пружања хитне медицинске помоћи и настале трошкове прегледа и превоза санитетским колима у случају неоправданог захтева за указивање хитне медицинске помоћи (Сл. гласник, 1/2013, чл. 51-55).

Питања хитне помоћи и транспорта пацијента обухваћена су такође правилима сталешког права, као и другим посебним законима из области здравствене заштите. Тако, правила професионалне етике Лекарске коморе Србије регулишу пружање хитне медицинске помоћи и рад у ванредним околностима тако што прописују дужност лекара да увек и на сваком месту пружи хитну медицинску помоћ лицу којем прети непосредна опасност по живот и здравље, у границама својих могућности и знања, без обзира на то да ли је на дужности или није и без обзира на то да ли је за помоћ изричито замољен или није (Сл. гласник,104/2016, чл. 8 и чл. 9). Ако је болеснику или повређеном лицу потребна медицинска помоћ коју лекар није у 
стању да пружи, дужан је да предузме одговарајуће мере да се пацијенту пружи адекватна здравствена заштита. Лицу које је свој живот довело у опасност из самоубилачке намере лекар треба да пружи хитну медицинску помоћ без обзира на његову вољу. Лекар је дужан да учествује у организацији и пружању медицинске помоћи у случају ванредних околности, односно епидемија, масовних несрећа, елементарних и других непогода. Од важности је и одредба која се тиче услуге трансфузије и која прописује да у ситуацији кад је пацијент прималац крви без свести, или из других разлога није у стању да изјави сагласност на трансфузију крви, хитно давање крви и компонената крви може се предузети и без сагласности примаоца крви, на основу мишљења надлежног доктора медицине који пружа хитну медицинску меру (Сл. гласник, 72/2009, чл. 25).

Правна питања здравствене заштите са становишта права пацијената у Србији постала су још од раније актуелна кроз законодавне реформе из 2005. године, а које су инициране од групе експерата и незваничне верзије акта повеље о правима пацијената (Радишић et al., 1999), чије су одредбе касније преузете као одредбе посебног поглавља тадашњег закона који је уређивао људска права у заштити здравља. У даљем нормирању ове области преовладао је став да је потребно усвојити посебан закон који се односи на права пацијената, а по узору на европске државе и данас важеће стандарде заштите пацијената у свету. Закон који кодификује основна права пацијената као корисника здравствених услуга примењује се на здравствене установе, приватну праксу и друге облике здравствених служби, и то како на здравствене раднике тако и здравствене сараднике који имају статус запослених у здравству (Сл. гласник, 45/2013). Закон полази од прокламованих начела у заштити и осигурању: приступ здравственим службама, правичност, свеобухватност, континуитет у третману лица, квалитет услуга и ефикасност рада. Закон уређује по члановима следећа права: право на приступ, на информације, на превентивне мере, на безбедност, на обавештење, на слободан избор, на друго стручно мишљење, на приватност и поверљивост, на пристанак, на увид у медицинску документацију, на поверљивост података о здравственом стању пацијента, право пацијента који учествује у медицинском истраживању, право детета у стационарним здравственим установама, право пацијента да на сопствену одговорност напусти стационарну здравствену установу, право на олакшавање патњи и бола, на поштовање пацијентовог времена, на приговор и право на накнаду штете (Сл. гласник, 45/2013, чл. 6-31). Особеност пацијентових права у свакодневној пракси здравствене заштите често захтева одређена појашњења. Опште место јесте свакако пацијентово самоодређење, док се појединачна права даље могу класификовати на одговарајући начин (X. Мујовић Зорнић, 2010). 
Национални закони, па и право Србије, управљају се према документима међународног и регионалног права. Такав документ представља Европска регулатива о правима пацијената (European Charter, 2002), која проблематику транспорта и помоћи пацијентима уређује у оквиру права на приступ услугама здравствене заштите. Њоме се предвиђа да свако лице има право приступа здравственим услугама које његове здравствене потребе захтевају. Здравствене установе треба да гарантују једнак приступ свакоме, без дискриминације на основама финансијских могућности, места пребивалишта, типа обољења или времена приступа услузи. Свако лице има право на одговарајућу услугу, без обзира на величину болнице или клинике у коју је примљено и свако лице има право на хитну и основну медицинску помоћ.

Упркос томе што у Србији постоји правни оквир за пружање помоћи здравствено угроженој популацији, па чак у неким сегментима и пренормираност, пракса здравствене заштите показује одређене проблеме. Нарочито је уочљиво да су питања транспортне медицине и интрахоспиталног пребацивања пацијената у једној мери изостављена из регулативе и више упућена на струковне акте због техничких и ускостручних параметара који се мере у тим ситуацијама. У прилог потребе боље покривености прописима у том делу говоре притужбе због грешака и нежељених догађаја у пружању услуга, које се спорадично дешавају, с тим што у Србији не постоји статистика о томе колико су присутне. Често се проблеми налазе у одсуству јасно дефинисаних критеријума за пријем, отпуст и премештање пацијената, недовољној координацији, као и непотпуној и неодговарајућој медицинској документацији. Право је у свим тим случајевима позвано да осигура квалитет здравствених услуга и да понашање даваоца услуга учини подложним друштвеној контроли, због тога што контрола медицинског сталежа није довољна и због тога што у кршењу правних обавеза могу лежати различити извори штета по појединце, које повлаче правну одговорност. Таква понашања се правно предупређују и санкционишу.

\section{3. ОСОБЕНОСТИ ПРАВНИХ ПИТАҢА УГРОЖЕНИХ ЛИЦА - ПАЦИЈЕНАТА}

\section{1. Правни аспекти рада медицинских служби}

Питања стандарда неге, пристанка, одговорности, документације, поверљивости и менаџмента исто тако су важна у транспорту као што су и у редовној клиничкој пракси. Од тога одступа и нарочито је и потенцијално много комплекснији рад у међународној ваздушној амбуланти јер он отвара проблеме јурисдикције, увоза и извоза лекова, међународне здравствене регулативе, рођења и смрти у 
току лета, што све постаје од додатне важности (Meenakshi Sundaram, 2007). Оперативни рад, па отуда и дужности медицинске службе хеликоптером у предболничком окружењу, слични су онима на земљи. Однос лекара и пацијента особен је, иако се код хитних стања и кризних ситуација многе од основних обавеза из тог односа деле са сестринским и парамедицинским особљем које и само предузима одређене радње у току транспорта пацијената. Једном кад лекар пружи консултацију, он улази у уговорни однос чак и у одсуству формалне узајамне сагласности, после чега уследи пацијентов захтев за дијагностичким и терапијским захтевима коју дужност лекар прихвата.

Процена која се даје пре отпочињања планираног или хитног транспорта први је корак који треба да идентификује или искључи проблеме од значаја за вођење сигурног трансфера. Оно што се укључује у фазу процене треба да буде резултат истраживања и посебног испитивања неопходног пре одлуке о транспорту и условима транспорта. Битно је да се сагледа улога сваког пре отпочињања транспорта, што ће некада захтевати споразум или други правни акт. Циљ прегледа у оквиру медицинског скрининга је да одреде да ли постоји хитно медицинско стање, укључујући ту животно или телесно претећа стања, велике болове или потенцијалну инвалидност за телесно оштећење и дисфункционалност, уколико би стање остало нетретирано. Медицинско испитивање у оквиру скрининга може захтевати укључивање ширих ресурса хитног одељења, укључујући лабораторијско тестирање, радиографску слику, консултацију супспецијализанта, како се то захтева и за дијагнозу. Без обзира на правила о пристанку у хитним стањима, са квалитетом неге и стабилизацијом пацијента не треба да се касни. Одлука да се пацијент пренесе у другу болницу доноси се од стране надлежног саветника у сарадњи са колегама одговарајућих специјалности из болнице која врши пријем. У оптималном случају, бира се најприкладнија болница пријема. Потребно је да се пацијент или његов законски заступник (супруг, сродник, блиско лице) сагласе са таквим преносом, премда се дешава да то није увек случај.

Сваки трансфер претпоставља уједно наставак лечења угроженог пацијента и због брзине и сложености ситуација је склона инцидентима. То указује да је од велике важности документовање транспорта. Клинички запис треба да сведочи о клиничком статусу пацијента пре, за време и након транспорта, као и о релевантним медицинским налазима, факторима средине и терапијама које су дате. Из документације такође треба да се види да су размотрени јасни детаљи поступања, уједно са сажетком закључка о сигурности транспорта. У документу протокола се наводи: начин транспорта, време поласка, праћење и истраживање путање, третмани и интервенције на путу, инциденти и последичне активности, значајне интеракције са па- 
цијентом, рођацима или трећим странама. Организације укључене у медицински превоз треба да имају делотворан систем управљања квалитетом који се могу пратити уз ревизију учинка. Требало би да тренутак у коме одговорност за пренос пацијента прелази са једне екипе на другу буде јасан свима који су укључени и он се посебно нотира у регионалном или националном протоколу за транспорт. Формална примопредаја између лекара који прати пацијента и оног који га прима такође је битна.

Одговорно медицинско поступање са етичког и правног становишта заснива се на четири фундаментална принципа, а она су: 1) обавеза лекара (здравственог радника) да пружи третман пацијенту, 2) обавеза да избегне штету, 3) поштовање права пацијената на самоодређење, 4) правична расподела средстава за здравствену заштиту. Питања се разматрају с обзиром на хронологију транспорта, акутну негу, рехабилитацију и дугорочно планирање. Правна разматрања нису увек иста нити се иста питања постављају за сваког пацијента. Полази се од закона и правних случајева. Инострана судска пракса стала је у једном предмету на становиште да сваки пренос пацијента намеће три обавезе: 1) скрининг пацијента, 2) стабилизовање пацијента, 3) трансфер и искрцај пацијента ради бољег третмана (Writ. Petition No 796, 1992).

У свему томе аутономија је једна од кључних одредница које дефинишу однос лекара и пацијента. Аутономија пацијента захтева поштовање његових вредности и жеља, а са̂м пристанак информисаног пацијента (енгл. informed consent) треба да испуни три критична елемента: 1) лице које пристаје треба да буде компетентно, 2) лице треба да буде обавештено и 3) лице треба да буде у стању да донесе одлуку. У стварању услова за компетентну одлуку полази се од тога да постоје различите дужности лекара и других пружаоца здравствених услуга везано за поступке информисања и оне су повезане са правима пацијента који проистичу из начела јавности и транспарентности у здравственој заштити. Најважнијим се сматра оно информисање које је део дужности узимања пристанка од пацијента. Неповредивост људског тела и добровољност лечења у обављању медицинске делатности представљају владајуће правило, од кога се може одступити само под законом стриктно одређеним условима. Владајуће начело је начело пристанка пацијента. Изузетак од начела пристанка постоји код хитних и неодложних стања у здравственој заштити и такво поступање је допуштено, без обзира на то да ли је реч о вољи, односно сагласности пацијента или замењујућој вољи његовог законског заступника. Лекар, односно други здравствени радник, има право предузимања медицинске мере противно вољи пацијента, односно његовог законског заступника, само у изузетним случајевима, који су утврђени законом и који су у складу са лекарском етиком (Сл. гласник, 45/2013, чл. 15, ст. 3). 
Код давања пристанка, није реч о општој обавези информисања, него о конкретном и појединачном обавештењу ради пристанка, које задовољава услове времена, обухвата и адекватности, а некад и форме у којој се даје. Закон изричито прописује да пацијента не обавезује пристанак коме није претходило потребно обавештење у складу са законом, а надлежни здравствени радник који предузима медицинску меру, у том случају, сноси ризик за штетне последице (Сл. гласник, 45/2013, чл. 16). Обавештење које се дугује у циљу добијања пристанка пацијента надлежни здравствени радник треба да саопшти усмено и на начин који је разумљив пацијенту, водећи рачуна о његовој старосној доби, образовању и емоционалном стању. Ако надлежни здравствени радник процени да пацијент, из било ког разлога, не разуме дато обавештење, обавештење се може дати члану пацијентове уже породице. Ако пацијент не познаје језик који је у службеној употреби на територији здравствене установе, треба да му се обезбедити преводилац, а ако је пацијент глувонем, потребан је тумач (Сл. гласник РС, 45/2013, чл. 11).

Одређене дужности код прибављања пристанка пацијента налажу и правила медицинског сталежа у Србији, према којима се ова дужност схвата шире јер се уско повезује са свим поступањима према пацијенту, почев од доласка лекару, па до низа обавештења у правцу конкретне медицинске мере. Тако, лекар поштује право психички способног и свесног пацијента да добро обавештен слободно изабере лекара, односно препоручену лекарску помоћ. Лекар је приликом пријема пацијента у здравствену установу дужан да се побрине да пацијент буде обавештен о рутинским поступцима и о медицинским техничким могућностима којима здравствена установа располаже, а односе се на његово лечење. За начин лечења лекар треба да добије пристанак пацијента, пошто га упозна са значајем захвата за утврђивање, лечење и праћење његове болести (Сл. гласник РC, 121/2007, чл. 42-45).

\section{2. Врсте транспорта}

Циљ транспорта пацијента је да се унапреди нега о пацијенту тако што ће се испитати расположивост третмана који су могући у другој болници или референтној установи. Транспорт може бити локални, регионални, национални и чак интернационални. Осим тога, он захтева често координацију више тимова, одељења и институција. То је, по правилу, сложен и потенцијално ризичан поступак. Као резултат тога, вештина и знање особља треба да буду добро промишљени, а не да се претпостављају.

Транспорти се могу поделити између оних унутар једне болнице (енгл. intra-hospital transport) и оних између различитих болница (енгл. inter-hospital transport). Ова подела изведена је са пра- 
ктичног, организационог и медицинског аспекта и сматра се да су то два основна типа транспорта. Називају се још примарни и секундарни транспорт. Каже се да интрахоспитални транспорт представља транспорт пацијента од места дијагностичке или терапијске процедуре до јединице интензивне неге и обрнуто. Транспорт тешких пацијената је сложен и захтеван, те да би се адекватно спровео потребан је спреман и едукован тим, као и стандардизована опрема. Осим што транспорт треба да се обавља сигурно, важно је и да користи по пацијента треба да превагну над ризицима. То исто показује да је медицински транспорт много више него „медицински такси”. Сигуран транспорт подразумева оптимизацију стања пацијента пре његовог отпочињања, а уједно и оптимизацију транспортног тима на тој релацији.

У погледу сарадње екипа, тј. тимског рада, разликују се такође ситуације где транспорт може да обавља: 1) тим болнице која је примарно примила пацијента ка установи више специфичности; 2) тим болнице која ће наставити лечење; 3) тим који не припада ни примарној ни примајућој установи. Одговорност над пацијентом и обавезу надзора и комуникације над пацијентом у транспорту има болница чији је тим (Hecker, Meier, 2017).

\section{3. Категорије пацијената у транспорту}

У погледу случајева правног вредновања конкретног поступања у транспорту, пракса рада са различитим угроженим лицима и пацијентима такође показује одређене специфичности. Субјекти транспорта могу бити трауматизовани пацијенти, критично оболели и новорођенчад (у првом дану живота, урођене мане).

\section{1) Трауматизовани пацијенти}

Када је у питању хитна медицинска помоћ, већи је опрез и забринутост током транспорта пацијента или жртве несреће у стању хитности, најчешће трауме. У строгом смислу, право тражи да се повређени транспортују чак и од лаика који нису здравствени радници, a у супротном се то сматра непажњом (пропуштање да се уради нешто што би разуман човек требало да уради, или чињење нечег што савестан и разуман човек не би учинио), а прописано је и кривично санкционисање таквих пропуштања (Сл. гласник, 108/2014, чл. 127).

\section{2) Критично оболели}

Када је у питању превоз критично оболелих пацијената, посебно се тражи да он буде спроведен од стране специјализованог тима, укључујући и лекара. Током транспорта постоје већи ризици за критично болесне пацијенте који имају ниску „психолошку резерву”. То је зато што пацијенти могу бити додатно у стресу када се померају, чак и на носилима. Они могу такође да буду искључени са монитора, 
што значи да су витални знаци привремено непознати. Када се склањају са позитивне вентилације и стављају на ручну, постоји ризик за размену гасова и да се оштети функција плућа. Сви ти фактори могу резултирати већом стопом смртности пацијената који се преносе. У неким државама као што су САД, ситуација је различита. Због недовољне регулаторне контроле, трансфери нису тако добро организовани, а тимови се најчешће састоје од медицинске сестре, болничара и возача/пилота. Слична пракса постоји и у Канади, где тимови често раде без лекара. Укључени болничари су добро обучени, са искуством у хитним случајевима, интензивној нези и транспортној медицини. Ипак, од стране многих се истиче да је у таквим поступцима неизоставно имати лекара интенсивисту, квалификованог и обученог за бригу о критично болесним пацијентима током преноса, кад треба пратити пацијента и бити одговоран за бригу о пацијенту. Сматра се да иако се особље може договорити о преносу, пратећи лекар би требало да буде одговоран за коначну одлуку да ли је пацијент за пренос или не, те да ли је за лечење током транспорта. Хитан транспорт може бити повезан са медицинским и парамедицинским особљем. Ако је лекар присутан у току транспорта, он ће бити правно позван да утврди смрт уколико се она у току транспорта деси (Alamanou and Brokalaki, 2014).

\section{3) Деиа и новорођенчад}

Специјализовани транспорт за децу и новорођенчад довео је до значајног пада у морталитету и морбидитету у овој популацији. Случајеви превоза педијатријских пацијената могу да буду нарочито сложени (Fanaroff, 2013). Ако се установи да нема хитности, онда то захтева уредно прибављање пристанка. У ситуацији када малолетник може да одлучује и у таквом је стању, а законски заступник није још доступан да изјави сагласност, здравствени професионалац може да пружи неопходни медицински третман или транспорт ради дефинитивне процене и стабилизирајућег третмана. Етички основ овог поступања налази се у професионалној дужности да се поступа у најбољем интересу детета. Правни основ који се примењује за предузимање радњи у случају хитности кад пристанак није могућ нити расположив јесте правило изузетка, познато као доктрина о претпостављеном пристанку. Правило је засновано на претпоставци да би свака разумна особа пристала на ту негу уколико би била у могућности да изјави пристанак и да би то исто учинио и законски заступник да је то знао. Према правилу о изузетку хитности, здравствени професионалац поступа као да има сагласност и овлашћен је да поступа ако су испуњена четири услова: 1) дете је у хитном стању које доводи у опасност његов живот и здравље; 2) законски заступник детета није доступан или је неспособан да се сагласи са третманом или транспортом; 3) третман или транспорт не могу бити сигурно одложени 
да би се добио пристанак; 4) даје се само третман за хитно збрињавање које изискује тренутно третирање детета. Свему овоме треба додати и могуће случајеве кад се сумња на злостављање и занемаривање детета, где надлежни старатељски и правосудни органи такође имају овлашћења за пристанак (Policy Statement, 2011).

\section{4. АКТУЕЛНА ПИТАЬА ОДГОВОРНОСТИ ЗА ТРАНСПОРТ}

\section{1. Опити поглед}

Домен санкционисања непрописног поступања у обављању транспорта у пракси прате различити основи одговорности. Некада се стандарди могу разликовати између појединих здравствених служби. Поред тога, у ситуацији кад поступа лекарски тим, најстарији лекар по хијерархији по правилу сноси одговорност за млађе. Онда кад је лекар присутан, он сноси крајњу одговорност за добробит пацијента, иако одговорност може бити подељена у односу на надређеног лекара који је вршио надзор. Однос између чланова тима треба да буде пажљиво разграничен - сви су узајамно зависни једни од других, при чему је од великог утицаја добро информисање и подношење извештаја како би се умањила могућност за потенцијалну одговорност. Медицинско и парамедицинско особље, као што су радници у амбуланти и лекари који воде транспорт, суочава се са ризиком одговорности, не само за сопствено чињење већ такође за оне који су им подређени или раде за њих. То је правни концепт одговорности надређеног. Према правилима о хијерархији, надређени се сматра одговорним за погрешне радње његових службеника када се оне тичу прописаних процедура (Радишић, 2008).

У начелу може се рећи да до транспорта долази када постоји извесно испланиран и уређен пут поступања у погледу дијагностике, интервенције или операције. Без тога се не улази у транспорт пацијента. Медицинска контрола и одговорност за пацијента је у рукама лекара у транспорту све до момента примопредаје. Међутим, у пракси се дешавају и ситуације када транспорт постаје споран. Јасно је да обављање транспорта пацијента може да доведе до опасности нежељених догађаја по здравље пацијента као што су: кардиолошки (тешка хипотензија или хипертензија, аритмије, срчани застој), респираторни (хипоксија, аспирација, екстубација, бронхоспазам, пнеумоторакс), неуролошки (агитација, интракранијална хипертензија), технички (батерије које су празне, проблеми са мониторингом), људски фактор (на пример, погрешно давање лекова). Неповољан утицај могу имати и неки технички фактори као што су механички вентилатори, инфузионе пумпе и мониторинг. Постоје такође друге мањкавости као недостатак обуке, увежбаности, лоша комуникација, неадекватан договор између 
болница. Стање пацијента некад прати хемодинамска нестабилност, респираторна инсуфицијенција (Нuе, 2007).

У циљу да се ризик по пацијента у току транспорта сведе на најмању меру, потребни су водичи праксе или протоколи. Они такође, посредним путем, улазе у изворе медицинског права. У развијеним државама они су већ дуже време усвојени као стандард, али се постављају такође питања њиховог познавања, ширег разумевања и добре праксе у њиховој примени (Нue, 2007).

Пропусте код спорова због грешака у професионалном поступању (енгл. medical malpractice) често представљају невођење документације или неправилности у њеном вођењу. Уредно бележење стања и процедура од суштинске је важности у контексту транспортне медицине управо због изразитих ризика које она носи. Вођење документације треба да по квалитету буде: редовно, јасно, концизно, комплетно, здружено и потписано са роковима и датумима. Усмене изјаве узимају се као непоуздане и оне нису материјални доказ на суду. Алтернатива може да буде у сачињавању списа о томе са датумом, временом и разлогом узимања изјаве. Измене у ретроспективи догађаја кад дође до спора доводе се најчешће у сумњу. На пример, диктафонске траке се не сматрају правним документом, премда оне могу бити коришћене ако су пренете у писану форму путем транскрипције или фајл у најранијем моменту када је то било могуће. У европском простору пацијенти имају приступ писаној медицинској документацији као и компјутерској документацији. Присутна су такође различита правна питања осигурања од одговорности, што је разумљиво јер су ризици транспорта иначе већи него обично поступање у пружању здравствене заштите, које по правилу искључује изражена питања сигурности (Sterling, 2001).

\section{2. Пример из судске праксе}

Сложеност ситуације транспорта може се најбоље сагледати на примеру случаја из иностране судске праксе - Sterling v. Johns Hopkins Hospital (www.caselaw.findlaw.com), будући да домаћих пресуда о томе нема. Чињенично стање је било следеће: Гђа Стерлинг је била трудница која се у Регионалном медицинском центру (ПРМЦ) због компликација јавила лекару др Грау, који је поставио дијагнозу тешке прееклампсије и потенцијалног Hellp синдрома. Дата јој је инфузија магнезијум-сулфата. Др Грау је позвао Центар за хитну медицинску службу (ЕМРЦ) ради договора да се пацијенткиња превезе у другу болницу. Трансфер се сматрао неопходним јер Регионални центар нема јединицу за неонаталну интензивну негу у исто време, а због забринутости да ће стање пацијенткиње захтевати превремени порођај детета. Обавештена је болница Johns Hopkins jep је она перинатални референтни центар који је требало контактирати. Др Грау се 
консултовала са лекаром друге болнице (др Khouzami) и пренела податке о пацијенткињи. Др Khouzami саветовао је да се у погледу превоза користе амбулантна кола хитне службе, премда је удаљеност болнице око два и по сата. Када је др Грау затражила да се обезбеди транспорт хеликоптером ради добијања у времену, др Khouzami je одговорио да верује да је друмски превоз прихватљив и да је то у складу с процедурама о јавним хитним санитетским возилима. Али, у току транспорта дошло је до интравентрикуларног крварења и смртног исхода по пацијенткињу. Превремено рођена девојчица је спасена. Покренута је парница пред судом против првотуженог Регионалног медицинског центра и друготужене болнице Johns Hopkins због грешке у дијагнози и третману компликација у трудноћи, као и гршака у транспорту, нестабилног стања пацијенткиње, што је све допринело смртном исходу. После првог рочишта, тужба је остала у погледу друготуженог, али пресуда није усвојила тужбени захтев као основан. Суд је стао на становиште, с једне стране, да je др Khouzami, иако као консултовани специјалиста, учествовао у одабиру начина транспорта, а да с друге стране чињенице показују да др Грау није одустао од контроле и неге пацијенткиње. Ако би се случај правно поставио између др Khouzami и пацијенткиње, произлази да међу њима није постојао однос лекара и пацијента, те да би на тај начин, упркос умешаности у одабиру начина транспорта, као стручњак др Khouzami могао бити изузет од одговорности. Суд је објаснио своје становиште следећим разлозима: тужена болница Johns Hopkins je преко свог запосленог преузела дијагнозу пацијенткиње са којом није имала никаквог контакта, потврдила да је лечење прикладно и пристала на пренос и прихватање пацијенткиње. Ниједна од тих радњи није обавезујућа у односу на могуће погоршање стања пацијенткиње. Не може се узети за претпоставку да болница која прихвата пренос има исте дужности као она која обавља транспорт, јер се није успоставила та врста одговорности за пружање конкретног лечења и проширење медицинске неге. Надаље, болница која прихвата нема овлашћења ни у погледу узимања пристанка информисаног пацијента. Према овом схватању, лекар који шаље пацијента у другу болницу задржава искључиву правну одговорност за бригу о пацијенту који се преноси све док он не буде преузет од другог лекара. У конкретном случају, упркос постојања консултације са специјалистом, чињеница је да је лекар центра који шаље пацијента имао коначну реч у вези са начином превоза за пренос. То је у складу са усвојеним и важећим професионалним правилима да лекари који шаљу пацијента имају одговорност за почетну процену и одређивање нивоа неге пацијента током транспорта, а лекари који примају пацијента имају дужности у погледу тога да је пријемна болница у стању да пружи потребну негу и прихвати пацијента. У образложе- 
њу пресуде суд не искључује да судови у другим државама могу доћи до различитих закључака, под истим или сличним чињеницама, нарочито имајући у виду потребан степен пажње у току транспорта, где екипи болнице која шаље пацијента може недостајати медицинско знање, а дужна је да осигура потребну негу у континуитету збрињавања и лечења (Sterling, 2001). Описани судски случај указује на важност споразума о међуболничком преносу пацијента, што би свакако помогло у разјашњењу и отклањању спорова до којих би могло да дође. Искуства развијених земаља могла би се сагледати и са ширег упоредног аспекта, са напоменом да су она слична. У погледу стања праксе медицинског транспорта, у Србији не постоје процесуирани случајеви пред неким од судова. Намера изнетог примера је да отвори таква размишљања и скрене пажњу на могуће ризике од одговорности.

\section{5. ЗАКЉУЧНЕ НАПОМЕНЕ}

Развој транспортне медицине условљен је на општем нивоу друштвеним развојем здравствених служби, подизањем стандарда здравствене заштите, а у конкретним сегментима заштите на нивоу развоја хитне и интензивне медицинске неге. За групације становништва које се налазе у стању потребе и ситуацијама кризним по живот и здравље људи, то је од виталног значаја. У том контексту, добијају на значају и прописи који уређују поступање медицинских професионалаца и здравствених установа у збрињавању група здравствено угрожених појединаца, а који су садржани у основним законима, правилницима и професионалним правилима.

Пружање адекватне помоћи и разрешење спорних ситуација некад условљавају и околности самог случаја. Стога се у циљу пружања заштите и помоћи становништву ради на сарадњи служби и на побољшању организационих и пратећих питања која могу бити подједнако техничке, медицинске, али и правне природе. Наиме, када је у питању правни део, здравствене установе требало би да користе уговоре који би ближе појаснили однос између субјеката који поступају у транспорту и здравствених установа, као и обавезе које погађају те односе. Посебно се има у виду споразум о међуболничком премештању пацијента, који може помоћи да се определе услови транспорта, као и да се разјасне одговарајуће дужности и методе како би се осигурало испуњење преузетих обавеза. Праксу и правну регулативу у области транспортне медицине у Србији треба даље развијати, у смислу бољих услова, познавања права и дужности, као и боље едукованости медицинских професионалаца, али и грађана који могу доћи у ситуацију да им затреба помоћ. То захтева боље разумевање прописа и праксе из домена медицинског права. Нека орга- 
низациона питања везана за хитну медицинску службу и ургентна одељења тренутно су, између осталих актуелних питања, изнета пред Парламент Србије у форми предлога измена и допуна закона из области здравствене заштите и свакако их у јавној расправи треба у целини сагледати не само са техничке и медицинске стране већ и са становишта права лица у транспорту.

\section{ЛИТЕРАТУРА}

ADAC Ambulanz Service Häufige Fragen zum Krankenrücktransport, https://www.adac. de/der-adac/ambulanceservice/faq/

Alamanou, D.G., Brokalaki, H. (2014). Intrahospital transport policies: The contribution of the nurse. Health Science Journal, 8 (1): 166-178.

Convention of Human rights and Biomedicine, Oviedo, 4 April 1997, www.tufts.edu/ departments /fletcher/multi/texts/biomed.txt

Brindley, P.G., Leary, T.O. (2011) Transportation of the Critically Ill: Moving in the Right Direction. (ed) Vincent, J.L. Springer Science +Business Media LLC. Brussels Belgium

Crippen, D (1990) Critical care transportation medicine: new concepts in pretransport stabilization of the critically ill patient. Am J Emerg Med 8(6): 551-4.

Declaration on the Promotion of Patients' Rights in Europe (1994) ICP/HLE 121, World Health Organization, Kopenhagen

Deutsch, E., Spickhoff, A. (2014) Medizinrecht. 7 Auflage Springer Berlin - Heidelberg: 4

European Charter of Patients' Rights - Basic document, Active Citizenship Network, Rome, 2002

Fanaroff, J.M. (2013) Legal Issues in Pediatric Transport. Sep 2013 • Clinical Pediatric Emergency Medicine

Guide for Interfacility Patient Transfer, National Highway Traffic Safety Administration. (2006) DOT HS 810 599: 5 https://www.ems.gov/pdf/ advancing-ems-systems/Provider-Resources/Interfacility_Transfers.pdf

Hecker, U., Meier, E. (2017) Unterwegs im Krankenhaus - Pflegerische Aufgaben beim Patiententransport (Top im Gesundheitsjob). Grundlagen. DOI 10.1007/978-3-662-53192-1_Springer-Verlag Berlin Heidelberg

Isakov, A. (2009) Urgent air-medical transport: Right patient, place and time. CMAJ. 2009 Oct 27; 181(9): 569-570.

Meenakshi Sundaram, A.L. (2007). Medicolegal Aspects of Critical Care Medicine, Indian Journal of Anaesthesia, 51 (4): 344-346.

Mémeteau, G. (2006) Cours de droit médical. Les Études Hospitaliéres Bordeaux: 41

Мујовић Зорнић, X (2010). Појам и развој пацијентових права: Пацијентова права у систему здравства [The concept and development of patient rights: Patient's rights in the health system], ИДН Београд: 20-21.

Policy Statement (2011) Consent for Emergency Medical Services for Children and Adolescents, American Academy of Pediatrics, Pediatrics Volume 128, 2: 427-433.

Радишић, J (2008) Медииинско право[Medicine Law]. Номос Београд: 137-143.

Радишић, Ј., Драшкић, М., Водинелић, В., Поповић, М., Стамболовић, В., Самарџић, М. (1999). Повеља о правима пацијената [Declaration on the rights of patients]. Право - Теорија и пракса, 12: 39-46.

Службени гласник РC (2006). Устав Републике Србије [Constitution of the Repiblic of Serbia], Службени гласник PC, бр. 83/2006. 
Радишић, J. (1986) Професионална одговорност медицинских посленика [Professional Responsibility of the Medical Employees]. ИДН Београд: 220

Службени гласник РС (2007). Кодекс медицинске етике Лекарске коморе Србије [Ccodex of the medical ethics of the Medical Chamberof Serbia], Службени гласник РС, бр. 104/2016.

Кривични законик Србије [Crime Law of Serbia], Службени гласник, бр. 85/2005, 88/2005 - испр., 107/2005 - испр., 72/2009, 111/2009, 121/2012, 104/2013, $108 / 2014$.

Службени гласник PC (2009). Закон о трансфузиолошкој делатности [THE Law on Trasfusion activity], Службени гласник РC, бр. 72/2009.

Службени гласник РС (2013). Правилник о ближим условима за обављање здравствене делатности у здравственим установама и другим облицима здравствене службе, Службени гласник РС, бр. 43/2006, 112/2009, 50/2010, 9/2011, 10/2012 - др. правилник, 119/2012 - др. правилник и 22/2013.

Службени гласник РС (2013). Правилник о начину и поступку остваривања права из обавезног здравственог осигурања, Службени гласник $P C$, бр. 10/2010, 18/2010 - испр., 46/2010, 52/2010 - испр., 80/2010, 60/2011 одлука УС и $1 / 2013$.

Службени гласник РС (2013). Закон о правима пацијената, Службени гласник $P C$, бр. 2013, 45/2013.

Службени гласник РС (2015). Закон о здравственој заштити Службени гласник РС, бр. 107/2005, 72/2009 - др. закон, 88/2010, 99/2010, 57.2011, 119/2012. и 45/2013 - др. закон, 93/2014, 96/2015. и 106/2015.

Службени гласник РС (2016). Правилник о садржају и обиму права на здравствену заштиту из обавезног здравственог осигурања и о партиципацији за 2016. годину [The Rulebook on the Content and Volume of the Right to Health Insurance according to the mandatory insurance as well as the participation for 2016] 9FUKLDDN, Службени гласник PC, бр. 12/2016.

Службени гласник PC (2016). Закон о здравственом осигурању [Law on Health Insurance], Службени гласник РC, бр. 107/2005, 109/2005 - испр., 57/2011, 110/2012 - одлука УС, 119/2012, 99/2014, 123/2014, 126/2014 одлука УС, 106/2015. и 10/2016 - др. закон.

Sterling, E., Personal Representative of the Estate of Laverne Sterling et al. v. Johns Hopkins hospital, Court of Special Appeals of Maryland, No.398, Sept. Term, 2001, decided: July 1, 2002.

Sterling et al. v. Johns Hopkins hospital, pristupljeno 22. 2. 2017. http://caselaw.findlaw. com/md-court-of-special-appeals/1451595.html

Videla-Haidik, M.H. (1988) Evaluation du transport hospitalier de malades. Politiques et Management Public Année 1998 16-4 : 75-99

Writ.Petition No 796/ 1992 High Court, pristupljeno 23. 2. 2017: www.judis.nic.in/ supremecourt/imgs1.aspx ?filename $=39734$ 


\title{
THE MEDICAL LAW ASPECTS OF TRANSPORTATION MEDICINE'S REGULATION
}

\author{
Hajrija Mujović \\ The Institute of Social Sciences in Belgrade, Center for Legal Research, Belgrade, \\ Serbia
}

\section{Summary}

The subject of this paper is to make closer clarification of the role and the specificities of services in transporting medicine by caring for vulnerable populations, or individuals who are in an emergency condition or critical situations. The field of medical transport presents a few legal questions and challenges. The aim is to research the rate of legal regulation and whether the legal and other regulation should be revised for reasons of achieving better health care of the endangered.The issues of performing different types of transport of patients are observed in cases where the transport emergency and when it is not an emergency but is done on the orders of a doctor, be it on intrahospital moving the patient, moving within health facilities, or at home treatment. Each hospital should have a formalized plan for intra- and interhospital transport that addresses: a) pretransport coordination and communication; b) transport personnel; c) transport equipment; d) monitoring during transport; and e) documentation. The transport plan should be developed by a multidisciplinary team and should be evaluated and refined regularly using a standard quality improvement process. Each transport of critically ill patients carries inherent risks. So equally important is a commitment to providing high-quality, compassionate clinical care in a team-based environment with excellent documentation and communication. The results of the legal analysis and the illustrated example from foreign jurisprudence are that when it comes to transport some of the patients' rights can be suspended under the condition of keeping a medical record properly. The urgency of transport is the reverse of the merits of enjoyment of the corresponding rights. The conclusion is that the regulations of Serbia in the field of healthcare under-cover transportation problems of patients. Some amendments to the regulations and draft decisions regarding the current work of emergency services are of more recent date and insufficiently implemented. There is no doubt that groups or individuals in transport deserve a better quality of transport services, as well as the effective protection of the complaints against the department. Developed countries, experience and legislation in this regard can be a good model for the Law of Serbia. This is very important because today some aspects of transport, the case of the so-called. air ambulances in the health care, have given international situation. 